\title{
Improving of the Mechanic Qualification Standard Related to Customer Satisfaction at Leading Heavy Equipment Distributor Company in Indonesia
}

\author{
${ }^{1,2}$ Baladi \\ ${ }^{1}$ United Tractors, Jakarta Timur- Indonesia \\ ${ }^{2}$ Master of Mechanical Engineering Swiss \\ German University \\ Tangerang City, Indonesia \\ baladi@unitedtractors.com
}

\author{
Dena Hendriana \\ Master of Mechanical Engineering \\ Swiss German University Tangerang \\ City, Indonesia \\ dena.hendriana@sgu.ac.id
}

\author{
Edi Sofyan \\ Master of Mechanical Engineering Swiss \\ German University Tangerang City, \\ Indonesia \\ edi.sofyan@lecturer.sgu.ac.id
}

\begin{abstract}
Product support services have an important role in the heavy equipment business because they are long-term relationship builder with customers which affects sales of heavy equipment. In product support services, mechanic has a dominant influence because apart from being a service provider, mechanic is also front liner who shapes customer perceptions regarding product support services. It makes mechanic as a top priority in the company's competency development programs. The main problem is how to align the mechanic development program with customer satisfaction. This study aims to arrange a competency development framework in the form of qualification standard which confirmed with customer satisfaction using the Quality Function Deployment (QFD). The correlation between qualification standard with customer satisfaction is analyzed by regression analysis on the Structural Equation Model (SEM) using the $\Omega$ nyq software. The finding of this research is the qualification standard with comprehensive requirements in Technical Operating Competency (TOC), Business Management Competency (BMC) and Behavior Competency $(B C)$ has better and consistent impact on customer satisfaction.
\end{abstract}

Keywords-competency development program, customer satisfaction, heavy equipment business, mechanic qualification standard, product support services.

\section{INTRODUCTION}

\section{A. Background}

Heavy equipment supports economic activities in the upstream industrial activities such as mineral and coal mining, forestry (logging) and agricultural business. Heavy equipment is also the main equipment in large-scale construction projects, such as the construction of highways, railroad tracks, dams or skyscrapers. Its condition makes heavy equipment have an important function in a vital project of the country. The majority of heavy equipment that circulate in Indonesia are foreign brands, even though several brands of heavy equipment have a production bases in Indonesia. Meanwhile, sales and distribution are held by local companies which are partners of the heavy equipment manufacturer. The company being studied is a heavy equipment distributor company from 5 leading brands. To deliver value to customers, the company has two main services, consisting of heavy equipment sales and product support services. Product support services consists of two activities, namely: spare parts sales and heavy equipment maintenance services. Apart from providing value to customers, a product support service is also a revenue generator for the company.

In recent years, the product support service business has become more important to the company's business. This condition is a result of fluctuations in coal prices which causes customers to optimize production costs. The optimization of production costs is carried out by extending the life time of the heavy equipment by better maintaining the heavy equipment. The best machine maintenance process held by mechanics will ensure customers get the best performance and life time from their heavy equipment during the production process, therefore the production costs are optimal. Mechanics are also indirect sales man for parts, with reliable parts recommendations bundled with quality installation work will make customers willing to buy parts because they are confident their parts and heavy equipment are handled properly. The important role of mechanics in the product support service business makes the development of mechanic competency become a top priority in company strategy [1]. The Competent mechanics will improve the quality of product support services so that customer expectations can be met and increase customer satisfaction and customer loyalty which has an impact to the company's competitiveness. The company runs a special program for the development of mechanic competency with a fund of IDR 30 million/mechanic/year and $7 \%$ of the mechanic's working time as a means of getting a competent mechanic.

\section{B. Research Problem}

The company has spent a lot of money and time on mechanical competency development programs, thus the results of this program must be evaluated to ensure the mechanical competency development can meet customer needs as indicated by the level of customer satisfaction. The competency development program of a mechanic is successful if the increase in the qualification level of the mechanic has a consistent and significant positive impact on increasing the level of customer satisfaction. Current conditions, increasing the qualification level of mechanics (Fig. 1.) does not have a positive impact on increasing the level of customer satisfaction (Fig. 2.) because in 2017 to 2019 the qualification level of mechanics has increased but 
the level of customer satisfaction related to mechanics has decreased 2.7 points.

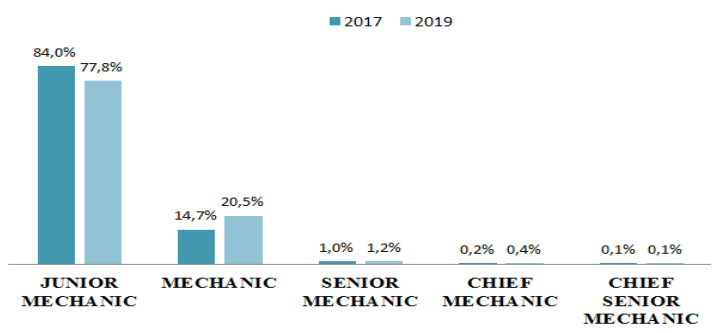

Fig.1. Mechanic qualification level movement

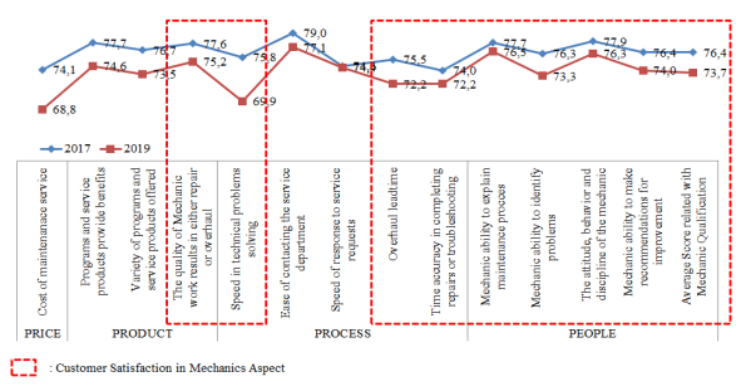

Fig.2. Service division's customer satisfaction index

The mismatch between the actual conditions and the theory raises the question: How to improve the qualification standards of mechanics align with customer needs, therefore the competency development program of the mechanics will have a positive impact on increasing customer satisfaction?

\section{Research Objectives}

To make improvement of the mechanic qualification standard which has the greatest impact on customer satisfaction.

\section{Research Questions}

- How to improve the mechanic qualification standard related with customer satisfaction?

- How do the improvement of the mechanic qualification standard impact to the customer satisfaction?

\section{E. Hypothesis}

The improvement of the mechanic qualification standard that refers to the customer need has positive impact on the customer satisfaction consistently.

\section{LITERATURE REVIEW AND RESEARCH METHODS}

\section{A. Qualification Standard}

The Presidential regulation number 8 of 2012 states that qualifications are mastery of learning outcomes. The qualification standard in Indonesia is the Kualifikasi Kerja Nasional Indonesia (KKNI) or also known as the Indonesian Qualification Framework (IQF) [2]. This qualification framework organizes qualifications into several levels, and each level has performance indicators that must be met. Qualifications bridge the equality of worker with experience in industry with graduates of educational institutions. IQF is determined with position and line of business, in each particular position a number of competency units must be mastered at each qualification level. IQF adopted the RMCS (Regional Model Competency Standard) to define competence . RMCS is a competency standard that focuses on the ability of someone to carry out roles and tasks in a particular function [3], the RMCS more focused on technical aspects or hard skills compared to soft skills aspects such as personal motivation, personal characteristics, abilities, and the other.

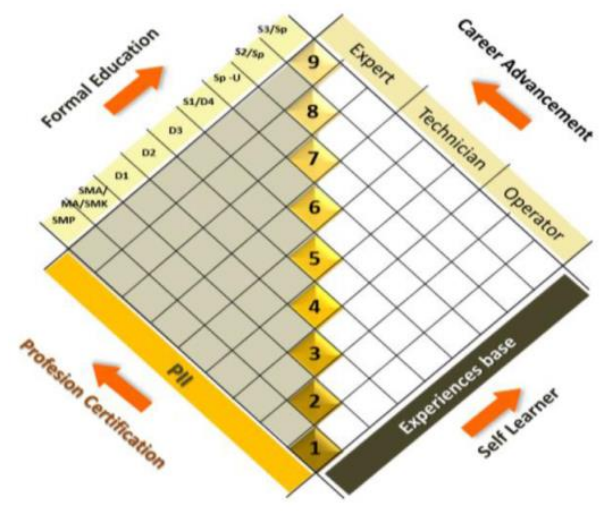

Fig. 3. Improving IQF through various pathway

In service companies it is impossible to develop employee qualifications only on hard skills, because companies must build long-term emotional relationships to ensure customer satisfaction and loyalty. This fact supported by studies that shown the importance of soft skills to improve performance and output quality and customer satisfaction [4]. Regarding customer satisfaction, behavioral competencies have a more significant direct impact than technical competencies, especially for new customers [5]. Behavior competencies with a significant effect on customer satisfaction are emotional competence, empathy, relationship, personal services, compliance with norms, willingness to help, understand the customer needs, the behavior alows customer to trust our services, discipline, responsibility, courtesy and hospitality.

The mechanic qualification standard in the studied company based on the number of competencies mastery that are quantified in the form of points. Point of competence is a method that bridges the number and weight of mastery of mechanical competence, which is determined based on the level of difficulty, work risk and its impact on the company. Mastery of mechanics in a competency is determined by assessment for mechanical mastery in all aspects of competence in the form of skills, knowledge and attitudes. The points will be given three times for each competency based on the level of proficiency as a result of the assessment, namely: competent, proficient and expert. Competency points will be accumulated to determine the grade of mechanics, while the qualifications of mechanics are determined based on the grouping of the grades (Fig. 4.). 


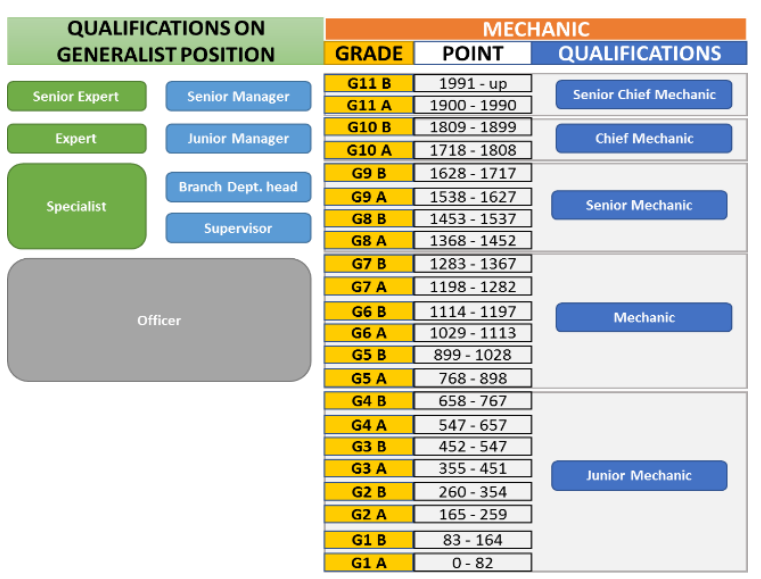

Fig. 4. Mechanic qualification based on grade and point groupings, and the equivalence with other positions [6]

Competency in company consists of three types of competencies : TOC, BMC and $\mathrm{BC}$, but for determining the grade of mechanics only based on TOC. BMC and BC are only applied as a check on changes in the qualification of mechanic at the senior mechanic level up to the senior chief mechanic known as hard screen, therefore mechanical qualifications are determined by mastery of mechanics in the TOC. The TOC definition is carried out in accordance with Model Occupational Skill Standard (MOSS), which is determined based on a mechanic's job list in product support services. This job list is divided into 4 groups, namely preventive maintenance, component replacement, troubleshooting and component overhaul. In addition, the list of competency is divided by application based on the type and size of heavy equipment, so if a job is implemented on a different type or size of heavy equipment, the job will also become a separate competency (Table I)

TABLE I

TECHNICAL OPERATING COMPETENCIES OF MECHANIC [6]

\begin{tabular}{|c|c|c|c|c|c|}
\hline SPECIALISM & GROUP & \multirow{2}{*}{ COMPETENCT } & \multicolumn{3}{|c|}{ POINT } \\
\hline & & & c & $\mathbf{P}$ & $E$ \\
\hline $\begin{array}{l}\text { Off highway } \\
\text { Dumptruck }\end{array}$ & \begin{tabular}{|l|} 
Preventive \\
Maintenance
\end{tabular} & $\begin{array}{l}\text { Periodic Inspection_Off highway } \\
\text { Dumptruck }\end{array}$ & 6 & 7 & 8 \\
\hline \begin{tabular}{|l|} 
Off highway \\
Dumptruck
\end{tabular} & \begin{tabular}{|l|} 
Preventive \\
Maintenance
\end{tabular} & $\begin{array}{l}\text { Periodic Service_off highway } \\
\text { Dumptruck }\end{array}$ & 14 & 18 & 20 \\
\hline \begin{tabular}{|l} 
Off highway \\
Dumptruck
\end{tabular} & \begin{tabular}{|l|} 
Preventive \\
Maintenance
\end{tabular} & etc & & & \\
\hline \begin{tabular}{|l} 
Off highway \\
Dumptruck
\end{tabular} & \begin{tabular}{|l|} 
Component \\
Replacement
\end{tabular} & $\begin{array}{l}\text { Engine Assy Replacement_Off } \\
\text { highway Dumptruck }\end{array}$ & 18 & 23 & 25 \\
\hline $\begin{array}{l}\text { Off highway } \\
\text { Dumptruck }\end{array}$ & $\begin{array}{l}\text { Component } \\
\text { Replacement }\end{array}$ & $\begin{array}{l}\text { Engine Turbocharger } \\
\text { Replacement_Off highway Dumptruck }\end{array}$ & 6 & 7 & 8 \\
\hline $\begin{array}{l}\text { Off highway } \\
\text { Dumptruck }\end{array}$ & \begin{tabular}{|l} 
Component \\
Replacement
\end{tabular} & etc & & & \\
\hline \begin{tabular}{|l} 
Off highway \\
Dumptruck
\end{tabular} & \begin{tabular}{|l|}
$\begin{array}{l}\text { Component } \\
\text { Overhaul }\end{array}$ \\
\end{tabular} & $\begin{array}{l}\text { Resealing Wheel Brake_Off highway } \\
\text { Dumptruck }\end{array}$ & 14 & 18 & 20 \\
\hline $\begin{array}{l}\text { Off highway } \\
\text { Dumptruck }\end{array}$ & $\begin{array}{l}\text { Component } \\
\text { Overhaul }\end{array}$ & $\begin{array}{l}\text { Engine Cylinder Head_Off highway } \\
\text { Dumptruck }\end{array}$ & 30 & 39 & 42 \\
\hline $\begin{array}{l}\text { Off highway } \\
\text { Dumptruck }\end{array}$ & $\begin{array}{l}\text { Component } \\
\text { Overhaul }\end{array}$ & (1) & & & \\
\hline $\begin{array}{l}\text { Off highway } \\
\text { Dumptruck }\end{array}$ & Troubleshooting & $\begin{array}{l}\text { Troubleshooting Engine System_Off } \\
\text { highway Dumptruck }\end{array}$ & 26 & 34 & 36 \\
\hline \begin{tabular}{|l} 
Off highway \\
Dumptruck
\end{tabular} & Troubleshooting & $\begin{array}{l}\text { TroubleshootingPower Train } \\
\text { System_off highway Dumptruck }\end{array}$ & 20 & 26 & 28 \\
\hline $\begin{array}{l}\text { Off highway } \\
\text { Dumptruck }\end{array}$ & Troubleshooting & etc & & & \\
\hline
\end{tabular}

The arrangement of the competencies that is based on a job list causes the mastery of a mechanic's competency really depends on his work experience. Each sector and work location has very different job characteristic for product support services, due to different models and types of heavy equipment, besides that the application is also different. Different models and types and their applications will cause different patterns of problem, so that maintenance patterns, damaged components and handling work will also be different. Differences patterns in each sector and location of heavy equipment support, will also generate the different pattern of the mechanic competency mastery. Both scenarios allow mechanic to get the same points and same grade or qualification but have different proficiency. This condition is not in line with the IQF, the IQF level is determined based on the proficiency level in a sector of work which in the industrial sector.

\section{B. Quality Function Deployment (QFD) Method}

The Quality Function Deployment (QFD) is a Japanese management approach that was introduced starting in 1972. The purpose of QFD was to enable all workers to contribute to the design of new products in line with Company Wide Quality Control (CWQC) in the Japanese management approach. In principle, this method is a Matrix Diagram (MD) method that uses 4 matrices consisting of: customer requirements, assessment requirements, product design and performance assessment. QFD Method is very effective for making product design that meet customer requirements. The purpose of QFD is to "deploy" the customer's voice to all design lines and cross-functional teams create a House of Quality (HoQ) matrix for ensure all product features match customer requirements.

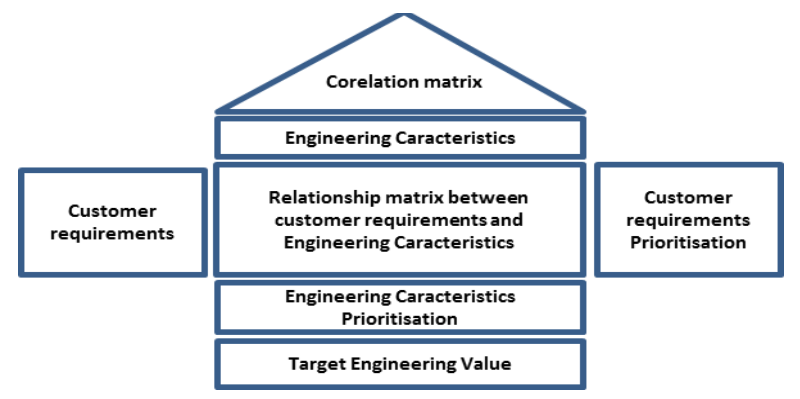

Fig. 5. The House of quality (HoQ) [7]

The main objective of HoQ is to convert customer requirements into engineering characteristics and establish target values for the product. HoQ is a matrix for describing the conceptual map in the product design process. HoQ is a construction to collect and understand customer requirement and find the prioritize of the product features characteristics needed to fulfill it. QFD method is a flexible method applied in many fields, such as creating training and curriculum design [8].

\section{Customer Satisfaction}

Customer satisfaction is the compatibility between the customer and what the customer receives, not limited to the services or products provided but how the service or product is delivered. The Research found that customer satisfaction is influenced by satisfaction with employees, product usability, and the ability to build emotional relationships with customers. The measurement of customer satisfaction using a questionnaire and using interviews [9] [10].

\section{Correlation Test}

Correlation test is a process to test the impact of a variable on other variables in the form of a single variable 
or multivariate. Many methods are used by researchers to conduct correlation test, the most important is how to choose the right method in accordance with the research objectives and character of the data. Many examples of methods used by researchers in testing an existing variable on customer satisfaction, among which are used are: Structural Equation Modeling (SEM) with AMOS software or Partial Least Squares (PLS), Statistical Package for the Social Sciences (SPSS) [9][11][12].

\section{E. Research Methods}

The process flow and research steps are as shown in Fig.6.

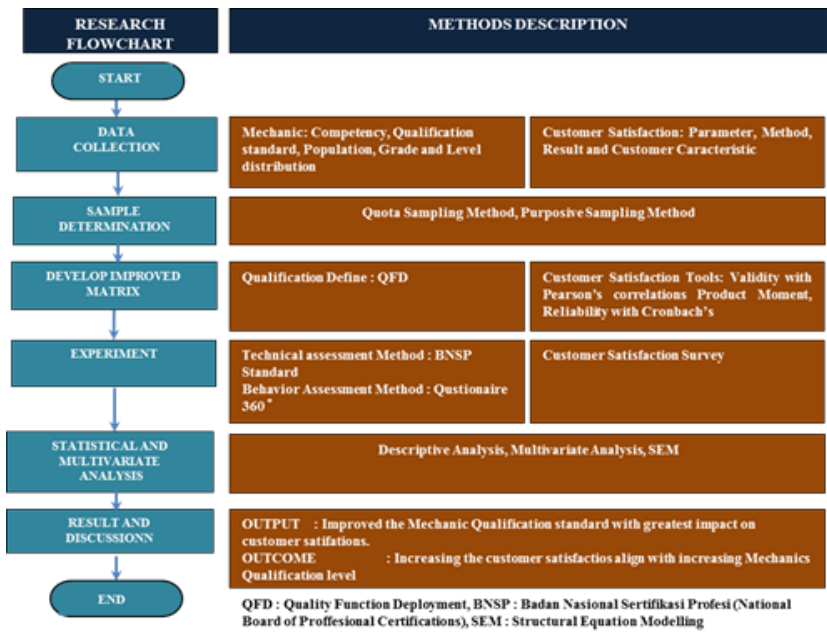

Fig. 6. Research flowchart and methods

\section{RESULTS AND DISCUSSIONS}

\section{A. Improvement of Mechanic Qualification Standard}

Voice of customer are obtained based on the results of a questionnaire survey broadcast to selected customers based on the intensity and quantity of transactions with the service division, the survey received responses from 34 respondents. The results of the validity test using Pearson's Correlation Product Moment show that all questionnaire items are valid ( $r>r$ table)[13], and the reliability test using the Cronbach's alpha test method, the resulting alpha 0.942 which is greater than 0.7 [14] so it is reliable. The result of survey shows that there is a gap between the importance of something to the customer and the company's competitiveness, indicated by the distribution of the score item requirements that are below the ideal area (Fig. 7.).

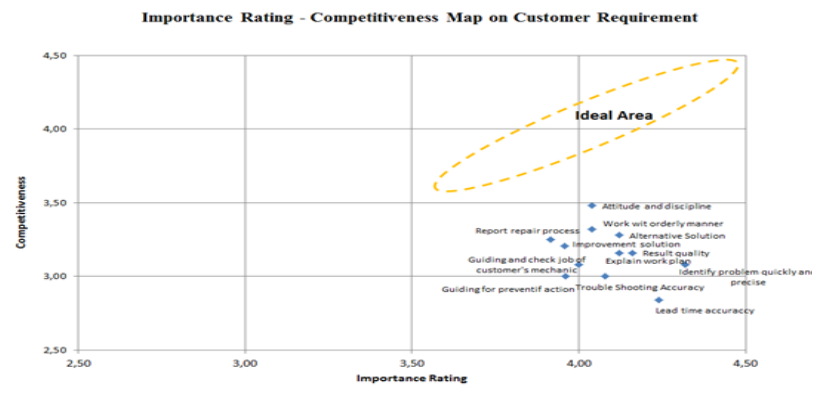

Fig. 7. Importance rating - competitiveness map for customer requirement analysis [9]
Determination of competency requirements in improving qualifications is carried out by convert the importance rating and competitiveness from customer requirements into the importance rating and competitiveness of mechanic competency with the bridging relationship score that has been determined in QFD, the results of this process can be seen in Fig.8.

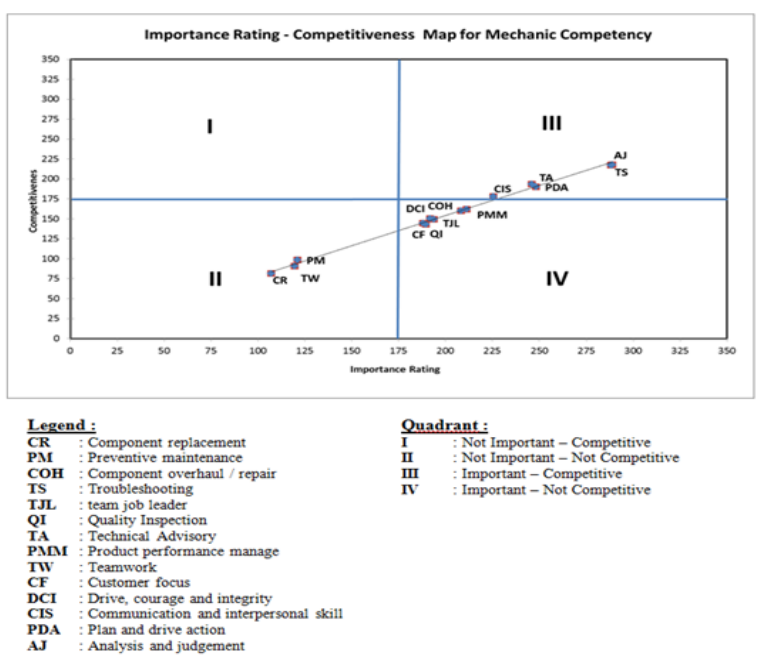

Fig. 8. Importance rating - competitiveness map for mechanic competency [9]

Based on the map of importance rating and competitiveness for mechanic competency, the development of mechanic competency in the right direction. It is indicated by a linear pattern between importance rating and competitiveness, which indicates the competencies with high important rating to customer has high competitiveness. But based on the level of competitiveness, the competency of mechanic is still lacking, because it is still below the diagonal line and there are also many competencies in quadrant IV.

The competency of mechanic consists of 3 groups, namely TOC, BMC, and BC. Each of these competency group has fundamental differences in both the rating scale, assessment method and the characteristic of its competency. TOC of mechanic is a main competency of mechanic to perform heavy equipment maintenance. TOC which has a proficiency aspect, which is determined by the level of mastery of the type of competence in maintenance work and the versality of the aspects that are determined by the mastery of various types of heavy equipment. Proficiency in practice has more effect on the performance of mechanics, therefore in TOC the proficiency ratio is higher than versality with a ratio of $7: 3$.

$\mathrm{BMC}$ of mechanic is a competency related to business or administrative processes to support the maintenance of heavy equipment. BMC for mechanic is quite simple, does not have many variants and proficiency level. BC of mechanic is a competency related to the soft skill of mechanic in its function to serve customer in heavy equipment maintenance. $\mathrm{BC}$ is the same for each qualification level of mechanic, but have different requirement in proficiency level. The proficiency level is determined based on the fulfillment numbers of the key performance in each competency, with results in the form 
of a score on 1-5 scale. In proposed mechanic qualifications standard, the weight of each competency in the competency scoring is determined based on the percentage of importance rating in QFD. The TOC competency score will be added up with the BMC and BC competency scores, and to simplify process, the score scale will be equalized into a scale of 1 to 100 . Therefore, TOC and BMC score must be multiply 100 for the scale equalization and BC score must be multiply 20 .

TABLE II

PROPOSEDMECHANIC QUALIFICATION STANDARD

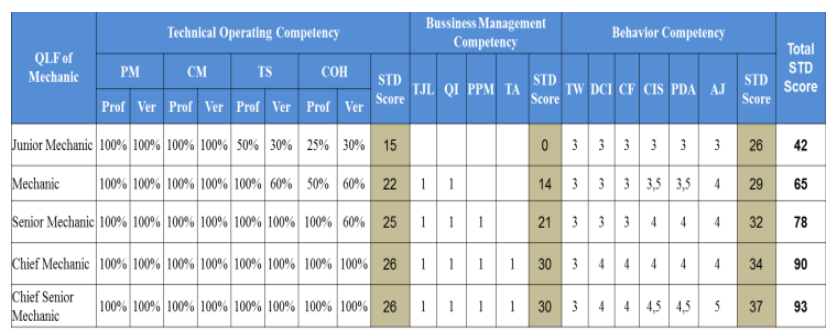

B. Implementation the Proposed Qualification of Mechanic

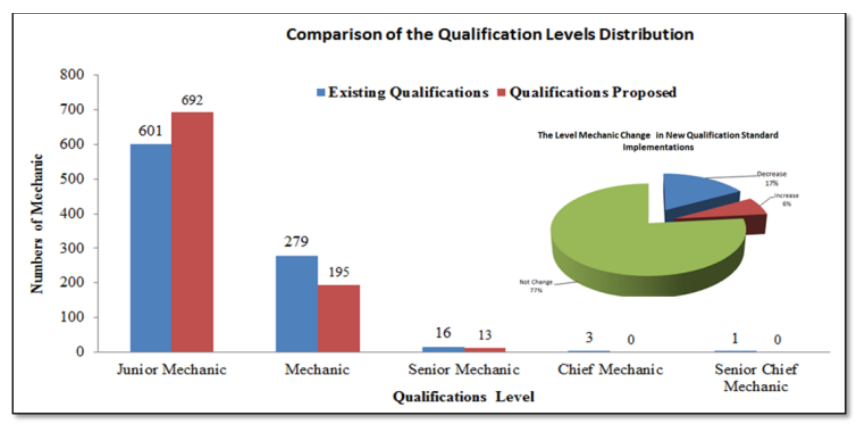

Fig.9. Comparison the distribution of mechanic qualification level based on existing qualification with proposed qualification

The implementation results show an increase in the number of mechanic at the junior mechanic level and a decrease at all levels above (Fig. 9). This condition indicates that several mechanics have met TOC standards but have not met the standard requirements of BMC and $\mathrm{BC}$ in the new qualification standards, especially at the senior level of mechanics and above. Although some mechanics with a good mastery of BMC and BC have an increase in qualification at the new qualification standard. This condition shows that the new qualification standard is more comprehensive and fair to occupy the mechanic level, because based on evaluate the mechanic with increase qualification are mechanic with high performance in mechanic competition events and innovation events.

\section{Result of Customer Satisfaction Survey}

The customer satisfaction survey was conducted on selected customers in each branch or support location with priority based on transaction frequency, and obtained feedback from 43 customers.. The composition of respondents in the customer satisfaction survey is in accordance with the mechanical composition as well as the profile and business composition of the company under study. The results of the validity test using Pearson's Correlation Product Moment show that all questionnaire items are valid ( $\mathrm{r}$ value $>\mathrm{r}$ table) [13], and the reliability test results using the Cronbach's alpha, showing the alpha value in this questionnaire is 0.917 . The results of this reliability test show that the questionnaire is reliable because the alpha value is greater than 0.7 [14].

TABLE III

SUMMARY RESUlT OF CUSTOMER SATISFACTION SURVEY

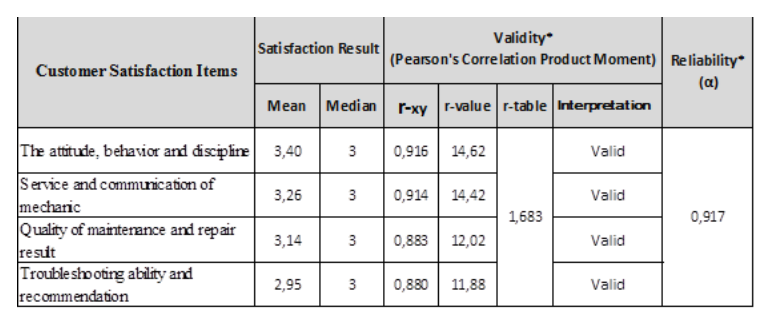

D. Correlation Analysis of The Mechanic Qualification Standard with Customer Satisfaction

The customer satisfaction survey is an assessment of customer related with the competency and services of mechanic. The result of this survey represents the customer satisfaction level with competency and services of mechanic in branch or site support generally. Customer satisfaction will measure the correlation to the qualifications of the mechanic. The qualification data of the mechanics are individual data, therefore for data equivalence it is necessary to determine the qualification trend at the branch or support site. In data with an asymmetrical distribution and not a bimodal distribution, the measurement of the tendency uses the mode [15]. Feedback from 43 customers resulted in customer satisfaction scores for 6 branches and 22 support sites, then the qualification mode of the 28 supporting points was analyzed for correlation with the level of customer satisfaction using SEM on the $\Omega$ nyq software.

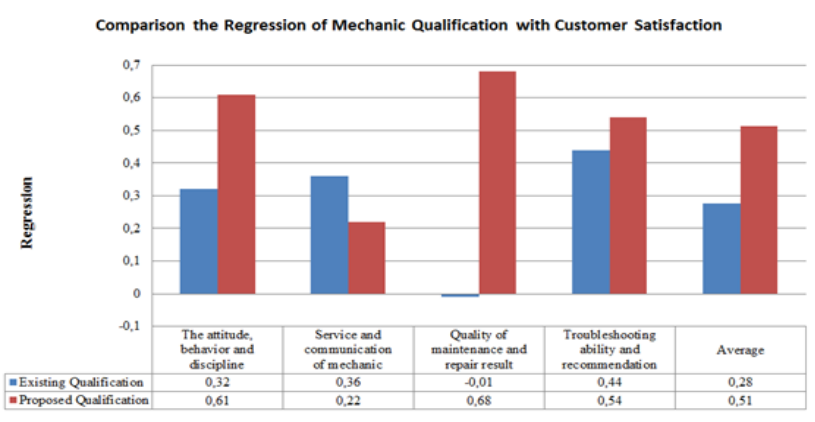

Fig. 10. Comparison the correlation of mechanic qualification standard with customer satisfaction from SEM result

SEM analysis results show the correlation between mechanical qualification standards with customer satisfaction on the proposed qualification standards compared to the existing qualification standards better in 3 aspects (behavior, attitude and discipline, quality of repair and maintenance as well as problem solving and recommendations), and decreasing in service and communication aspects (Fig. 10). The average impact of the proposed mechanical qualification standards is $185 \%$ (0.51 and 0.28) higher than the existing mechanical qualification standards. Analysis of significance, the existing mechanic qualification standard have unsignificant impact at repair and maintenance quality aspect, and had a 
moderate impact at other aspects. The proposed mechanic qualification standard have moderate impact at service and communication, troubleshooting and recommendation, and high impact at behavior, attitude and discipline, and repair and maintenance quality [16]. The results of significance analysis indicate that the proposed mechanic qualification standard has more significant and consistent impact on all measured customer satisfaction items compared to the existing mechanic qualification standard.

The conclusion is the mechanical qualification standard with comprehensive requirements of $\mathrm{TOC}, \mathrm{BMC}$, and $\mathrm{BC}$ on the proposed mechanical qualification standard has a higher and consistent impact on customer satisfaction with an increase of $185 \%$, therefore the hypothesis in this study is proven to be correct.

\section{CONCLUSIONS AND RECCOMENDATIONS}

\section{A. Conclusions}

- Improving the mechanic qualification standard using QFD is proven to align the qualification standard with customer requirement.

- The proposed mechanical qualification standard with comprehensive requirements on TOC, BMC, and BC has a higher and consistent impact on customer satisfaction with an increase of $185 \%$ over existing mechanic qualification standards.

\section{B. Recommendations}

To minimize resistance from mechanics to the implementation of the proposed mechanical qualification standards, by preparing a development program for mechanics who do not meet the requirements at the qualification level at the new qualification standard.

\section{ACKNOWLEDGMENT}

I would like to thank to everyone for the help during the research process. Mr. Dena Hendriana, and Mr. Edi Sofyan, for the advising. Mr. Edhie Sarwono, for the research opportunity. Mr. Rudy Poerwanto and Mr. Agus Suyitno for the data collection permit. Mr. Andrie Permadi, Mr. Yudistira and Miss Desy for the support in the customer satisfaction survey.

\section{REFERENCES}

[1] T. M. Simatupang and A. F. Hendarman, "An analysis of heavy equipment supply chain in supporting infrastructure construction," pp. 219-226, 2012.

[2] Menteri Ketenagakerjaan Republik Indonesia, "Peraturan Menteri Ketenagakerjaan Republik Indonesia Nomor 21 Tahun 2014 Tentang Pedoman Penerapan Kerangka Kualifikasi Nasional Indonesia." 2014.

[3] I. L. Office, R. Skills, and E. Programme, Guidelines for Development of Regional Model Competency Standards ( RMCS ). 2006.

[4] T. Chen, M. Fu, R. Liu, X. Xu, S. Zhou, and B. Liu, "How do project management competencies change within the project management career model in large Chinese construction companies?," Int. J. Proj. Manag., 37 (3), pp. 485-500, 2019, doi:

\subsection{6/j.ijproman.2018.12.002}

[5] N. Ramasubbu, S. Mithas, and M. S. Krishnan, "High tech, high touch: The effect of employee skills and customer heterogeneity on customer satisfaction with enterprise system support services," Decis. Support Syst., vol. 44, no. 2, pp. 509-523, 2008, doi: 10.1016/j.dss.2007.06.005.

[6] U. People Development, Fungsi dan Pengembangan Mekanik.

[7] S. Abu-Assab, Integration of Preference Analysis Methods into Quality Function Deployment A Focus on Elderly People, 2011.

[8] R. Gupta, S. Gupta, and K. Nagi, "Analysis \& Designing an Engineering Course Using QFD,” Int. J. Mod. Eng. Res., 2 (3), pp. 2-7, 2012, [Online]. Available: http://www.ijmer.com/papers/vol2_issue3/BF23896901.pdf.

[9] M. S. Farooq, M. Salam, A. Fayolle, N. Jaafar, and K. Ayupp, "Impact of service quality on customer satisfaction in Malaysia airlines: A PLS-SEM approach," J. Air Transp. Manag., 67, pp. 169-180, 2018, doi: 10.1016/j.jairtraman.2017.12.008.

[10] P. Gritti and N. Foss, Customer satisfaction and competencies: An econometric study of an italian bank, 17 (18), 2010.

[11] H. Kong and Q. Yan, "The relationship between learning satisfaction and career competencies," Int. J. Hosp. Manag., 41, pp. 133-139, 2014, doi: 10.1016/j.ijhm.2014.05.013.

[12] C. Delcourt, D. D. Gremler, A. C. r. Van Riel, and M. Van Birgelen, "Effects of perceived employee emotional competence on customer satisfaction and loyalty: The mediating role of rapport," J. Serv. Manag., 24 (1), pp. 5-24, 2013, doi: 10.1108/09564231311304161.

[13] Suhar Janti, "Prosiding Seminar Nasional Aplikasi Sains \& Teknologi (SNAST) 2014 Yogyakarta, 15 November 2014,” Snast, November, p. 159, 2014.

[14] E. Swanson, S. Kim, S. Lee, J. Yang, and Y. Lee, "Journal of Hospitality and Tourism Management The effect of leader competencies on knowledge sharing and job performance : Social capital theory," 42, pp. 88-96, 2020.

[15] S. Manikandan, "Measures of central tendency: Median and mode," J. Pharmacol. Pharmacother., 2 (3), pp. 214-215, 2011, doi: 10.4103/0976-500X.83300.

[16] P. Schober and L. A. Schwarte, "Correlation coefficients: Appropriate use and interpretation," Anesth. Analg., 126 (5), pp. 1763-1768, 2018, doi: 10.1213/ANE.0000000000002864. 